\title{
The role of parenteral tranexamic acid in reducing blood loss in normal labour
}

\author{
Nandhini C. C.*, Shanmugapriya \\ Department of Obstetrics and Gynecology, Government Theni Medical College Hospital, Theni, Tamil Nadu, India \\ Received: 25 August 2020 \\ Accepted: 01 October 2020 \\ *Correspondence: \\ Dr. Nandhini C. C., \\ E-mail: nubraganga@gmail.com \\ Copyright: ( $)$ the author(s), publisher and licensee Medip Academy. This is an open-access article distributed under \\ the terms of the Creative Commons Attribution Non-Commercial License, which permits unrestricted non-commercial \\ use, distribution, and reproduction in any medium, provided the original work is properly cited.
}

\begin{abstract}
Background: Obstetric blood loss can be reduced by using anti-fibrinolytic agents.

Methods: 200 patients undergoing normal vaginal delivery and fulfilling the inclusion criteria were recruited for the study. In each patient pre-delivery and post-delivery vital parameters and blood indices were noted. The study group received injection tranexamic acid while the control group received only placebo injection in addition to the active management of third stage of labour. The amount of blood loss immediately after delivery and 2 hours after delivery were measured using blood drape and pre-weighed pads respectively.

Results: There was a significant increase in the pulse rate and decrease in blood pressure in the control group. The postdelivery hemoglobin and hematocrit were significantly reduced in the control group. The blood loss at the end of 2 hours was more in the control group. The usage of additional uterotonics, need for blood transfusion, and duration of hospital stay was also increased in the control group.

Conclusions: Tranexamic acid injection, an antifibrinolytic agent given intravenously after the delivery of the baby appears to reduce blood loss during normal vaginal delivery effectively.
\end{abstract}

Keywords: Blood loss, Maternal morbidity, Tranexemic acid

\section{INTRODUCTION}

Child birth is one of the most cherished moments in a women's life. Labour natural is a unique experience and child birth is celebrated not only by the mother but the entire family. Though labour is a physiological process, it is often associated with morbidity and sometimes mortality. The most common cause of maternal mortality is blood loss. ${ }^{1}$ Life threatening obstetrical hemorrhage occurs in approximately 1 per thousand deliveries. ${ }^{2}$ Management of postpartum hemorrhage (PPH) is the critical point in saving mother's life. A lot of drugs are being used in management of PPH with the recent ones being antifibrinolytics and recombinant factor VIIa. ${ }^{3}$

The commonest cause of PPH is uterine atony due to failure of uterine myometrium to contract and retract after delivery, where uterotonics are used to control bleeding.
Other causes of PPH leading to maternal mortality are due to uterine rupture, retained placenta, inversion of uterus and other genital tract injuries including those encountered during cesarean section. ${ }^{4}$ Thus a considerable number of cases are not due to uterine atony and attempts to address the problem needs to go beyond the use of uterotonics. In particular, high risk factors which may not respond to uterotonics such as placenta previa and lacerations of genital tract may respond to tranexamic acid. ${ }^{5}$

The changes in fibrinolytic components during and immediately after delivery of placenta are consistent with fibrinolysis as a response to local fibrin deposition. The plasma fibrinogen levels decrease during the third stage of labour and after placenta delivery and the levels of fibrin/fibrin degradation products in the serum increases after child birth and remains elevated in early puerperium. ${ }^{6}$ Hence antifibrinolytics will be useful in reducing blood 
loss. ${ }^{6,7}$ This study observes the efficacy of tranexamic acid in reducing blood loss during third stage of labour.

\section{METHODS}

It is a prospective randomized study conducted between January 2020 - June 2020 involving 200 pregnant women who delivered by labour natural at term in the labour ward of Government Theni medical college hospital, Theni, Tamil nadu, India. 100 patients were randomized in study group and 100 patients in control group. Detailed history medical and obstetric were taken. Vital parameters were checked and basic investigations were done. Detailed general and obstetric examination were done. All the patients were counselled well and informed consent was obtained.

Study group received parenteral oxytocin 10 units within one minute of delivery and tranexamic acid $10 \mathrm{mg} / \mathrm{kg}$ in $100 \mathrm{ml}$ normal saline intravenous (IV) over 20 minutes. The control group received parenteral oxytocin 10 units within one minute of delivery and placebo of $100 \mathrm{ml}$ normal saline over 20 minutes intravenously. Study outcome was to compare the efficacy of parenteral tranexamic acid in reducing blood loss during normal labour and comparing it with the amount of blood loss in patients who received placebo.

Primary outcomes include reduction in blood loss after parturition and changes in blood indices in both the groups. Secondary outcome include requirement of maternal blood transfusion, usage of any additional uterotonics, maternal and fetal complications and duration of hospital stay.

Inclusion criteria in the study were primigravida and second gravida, more than 38 weeks of gestation, spontaneous or induced labour. Exclusion criteria were multiple pregnancy, hemoglobin less than $8 \mathrm{~g} / \mathrm{dl}$, macrosomia estimated fetal weight (EFW) greater than 4 $\mathrm{kg}$, polyhydramnios, placenta previa, and abruption, preeclampsia, patients on anticoagulants, previous history of thromboembolism, renal or liver disease and multigravida more than or equal to three.

The following parameters were noted in both groups after receiving the injections pre-delivery pulse rate, blood pressure, hemoglobin $(\mathrm{Hb})$ gm $\%$ and packed cell volume (PCV) \%, blood loss from delivery of the baby to 2 hours postpartum, side effects of the drug, postpartum pulse rate, blood pressure, $\mathrm{Hb}$ gm $\%$ and $\mathrm{PCV} \%$, maternal needs for blood transfusion, and maternal outcome till discharge.

Immediately after delivery of the baby when all liquour was drained, the patient was brought to the edge of the table. The patient was placed over a blood drape, a disposable conical graduated plastic collection bag. The amount of blood collected in the blood drape was measured. Then the patient was given pre-weighed pads, which was weighed after 2 hours. In our study, blood loss was measured by measuring the blood collected in the drape and by weighing the pads before and after delivery. Total blood loss (ml) was calculated by adding blood in the drape $(\mathrm{ml})$ with pad weighed after 2 hours (gm) and subtracting the weight of pad weight prior to use (gm).

The side effects of the drugs, if any were noted. The patient was shifted to the postnatal ward after she passed the urine. The patient's post-delivery pulse rate, blood pressure, $\mathrm{Hb}$ $\mathrm{gm} \%, \mathrm{PCV} \%$ were also noted. Any significant drop in $\mathrm{Hb}$ gm\%, PCV\%, need for blood transfusions and parenteral iron infusions postpartum were noted. After collecting all the data, they were tabulated in a master chart and analyzed. Using the software frequencies, percentages, mean, standard deviation, $p$ values were calculated. A p value less than 0.5 is taken to denote significant relationship.

\section{RESULTS}

The total number of patients were 200 - equally distributed in both the groups. The majority of patients belonged to age group 21-25 years and had their body mass index (BMI) between $24-26 \mathrm{~kg} / \mathrm{m}^{2}$. In our study, the study group had $56 \%$ primigravidas and $44 \%$ second gravidas, while the control group had $59 \%$ primigravida and $41 \%$ second gravida.

In our study all cases in both control and study group were booked. Proper antenatal care is essential to identify the high risk factors in the antenatal period itself and to correct them thereby reducing the incidence of PPH. In our study $48 \%$ in study group had induced labour and $50 \%$ in control group had induced labour. Both groups were comparable.

Table 1: Variations in vital parameters.

\begin{tabular}{|llll|}
\hline Parameter & $\begin{array}{l}\text { Study } \\
\text { group }\end{array}$ & $\begin{array}{l}\text { Control } \\
\text { group }\end{array}$ & P value \\
\hline Pulse rate (bpm) & & & \\
\hline Pre-delivery & 78.7 & 78.11 & \\
\hline Post-delivery & 79.2 & 82.62 & $<0.0001$ \\
\hline Difference & +0.5 & +4.51 & \\
\hline Systolic BP(mm Hg) & & & \\
\hline Pre-delivery & 114.74 & 118.64 & \\
\hline Post-delivery & 113.52 & 114.14 & $<0.0001$ \\
\hline Difference & -1.22 & -4.50 & \\
\hline $\begin{array}{l}\text { Diastolic BP }(\mathbf{m m} \\
\text { Hg) }\end{array}$ & & & \\
\hline Pre-delivery & 76.76 & 76.22 & \\
\hline Post-delivery & 75.18 & 75.42 & $<0.0001$ \\
\hline Difference & -1.52 & -2.80 & \\
\hline
\end{tabular}

The mean increase in pulse rate was 0.5 beats per minute (bpm) in study group and $4.51 \mathrm{bpm}$ in control group. The mean fall in systolic blood pressure (BP) was $1.22 \mathrm{~mm} \mathrm{Hg}$ in study group and $4.50 \mathrm{~mm} \mathrm{Hg}$ in control group. Mean fall in diastolic BP was $1.52 \mathrm{~mm} \mathrm{Hg}$ in study group and $2.80 \mathrm{~mm} \mathrm{Hg}$ in control group. There was a statistically 
significant increase in pulse rate and decrease in BP in the control group as compared to the study group (Table 1).

The mean fall of $\mathrm{Hb}$ was $0.61 \mathrm{gm} \%$ in the study group and $0.87 \mathrm{gm} \%$ in the control group. Mean fall in hematocrit was $1.87 \%$ in study group and $3.10 \%$ in control group. The post-delivery $\mathrm{Hb}$ and hematocrit were significantly reduced in control group as compared to study group. In our study, there was a significant reduction of blood loss in study group. The mean blood loss was $116.81 \mathrm{ml}$ while in control group the blood loss was $172.52 \mathrm{ml}$. $4 \%$ of the patients in control group required additional uterotonics compared to only $1 \%$ in the study group. Thus the drug significantly reduces the need for additional uterotonics. The patients who needed additional uterotonics had atonic PPH and were treated with injection carboprost, and rectal misoprostol 600 microgram (Table 2).

Table 2: Variation in blood indices.

\begin{tabular}{|lcll|}
\hline Parameter & $\begin{array}{c}\text { Study } \\
\text { group }\end{array}$ & $\begin{array}{l}\text { Control } \\
\text { group }\end{array}$ & P value \\
\hline Hemoglobin & (gm \%) & & \\
\hline Pre delivery & 10.73 & 10.22 & \\
\hline Post delivery & 10.12 & 9.35 & $<0.0001$ \\
\hline Difference & -0.61 & -0.87 & \\
\hline PCV\% & & & \\
\hline Pre delivery & 35.30 & 31.79 & \\
\hline Post delivery & 33.49 & 28.69 & $<0.0001$ \\
\hline Difference & -1.81 & -3.10 & \\
\hline
\end{tabular}

There was a significant difference in the need for blood transfusion between the two groups. In the study group $2 \%$ needed transfusion compared to $15 \%$ in the control group (Table 3).

Table 3: Usage of additional uterotonics.

\begin{tabular}{|lllll|}
\hline Additional & \multicolumn{2}{c|}{ Study group } & \multicolumn{2}{c|}{ Control group } \\
uterotonics & No. & \% & No. & \% \\
\hline Yes & 1 & 1 & 4 & 4 \\
\hline No & 99 & 99 & 96 & 96 \\
\hline P value & $<0.001$ & & & \\
\hline
\end{tabular}

$2 \%$ of the patients in the study group had to stay for more than 3 days as they were anemic and needed transfusion and parenteral iron. $15 \%$ of patients in control group were anemic and transfused blood (Table 4) and had to stay for more than 3 days.

Table 4: Requirement of blood transfusions.

\begin{tabular}{|lllll|}
\hline Blood & \multicolumn{2}{l|}{ Study group } & \multicolumn{2}{c|}{ Control group } \\
transfusions & No. & \% & No. & \% \\
\hline Yes & 2 & 2 & 15 & 15 \\
\hline No & 98 & 98 & 85 & 85 \\
\hline P value & $<0.01$ & & & \\
\hline
\end{tabular}

$3 \%$ of patients in control group were also discharged later than 3rd postnatal day as they had fever with breast engorgement. There were no significant difference in maternal complications like vomiting, diarrhea and fever between the two groups (Table 5).

Table 5: Duration of hospital stay.

\begin{tabular}{|lllll|}
\hline Hospital & \multicolumn{2}{c|}{ Study group } & \multicolumn{2}{c|}{ Control group } \\
\cline { 2 - 5 } stay (days) & No. & \% & No. & $\%$ \\
\hline$>\mathbf{3}$ & 2 & 2 & 15 & 15 \\
\hline$<3$ & 98 & 98 & 85 & 85 \\
\hline
\end{tabular}

\section{DISCUSSION}

Our study was aimed at proving the efficacy of tranexamic acid - an antifibrinolytic agent in the primary prevention of PPH - the major but preventable cause of maternal mortality. In our study, mean post-delivery increase in pulse rate was $0.5 \mathrm{bpm}$ in study group and $4.51 \mathrm{bpm}$ in control group. The mean fall in systolic BP was $1.2 \mathrm{~mm}$ $\mathrm{Hg}$ in study group and 4.50 in control group. Mean fall in diastolic BP was $1.52 \mathrm{~mm} \mathrm{Hg}$ in study group and $2.80 \mathrm{~mm}$ $\mathrm{Hg}$ in control group. There was a significant difference in fall of blood pressure both systolic and diastolic and rise in pulse rate between the study and control group. This is comparable to the study conducted by Novikova et al. ${ }^{8}$

Our study documented a statistically significant fall in $\mathrm{Hb}$ gm \% in control group as compared to study group in concordance to a similar study by Sotlani et al. ${ }^{9}$ Further there was a statistically significant reduction in blood loss in the postpartum period. Mean blood loss within 2 hours after delivery was $116.81 \mathrm{ml}$ in study group and $172.52 \mathrm{ml}$ in control group. This result is similar to a study by Tesseir et al. ${ }^{10}$

$4 \%$ of the patients in control group required additional uterotonics compared to only $1 \%$ of our study group. Thus significant decrease in the need of additional uterotonics has been recorded, as also noted in previous trials. ${ }^{11}$ Only 2 patients $(2 \%)$ in the study group compared to 15 patients $(15 \%)$ in the control group needed blood transfusions. This observation is similar to study by Litch et al and Gokhan et al. ${ }^{12,13}$

$15 \%$ of the patients in the control group had to stay for more than 3 days compared to $2 \%$ in the study group. The patients in both group who stayed for more than 3 days were anemic and needed blood transfusions and parenteral iron therapy. This is in concordance with the study by Ray et al.

\section{CONCLUSION}

Prevention is always better than cure and tranexamic acid, an antifibrinolytic agent when given prophylactically after the delivery of the baby by intravenous route appears to reduce the blood loss during normal delivery effectively. ${ }^{14}$ 
We can advocate its use as an adjunct to oxytocin for regular management of third stage of labour.

Funding: No funding sources

Conflict of interest: None declared

Ethical approval: Not required

\section{REFERENCES}

1. Henry DA, Carless PA, Moxey AJ, O'Connell D, Stokes BJ, Fergusson DA, Ker K. Antifibrinolytic use for minimizing perioperative allogenic blood transfusion. Cochrane Database Syst Rev. 2007;4:CD001886.

2. Lethaby A, Farquhar C. Antifibrinolytics for heavy menstrual bleeding. Cochrane Database Syst Rev. 2000;4:CD000249.

3. Gai MY, Wu LF, Su QF, Tatsumoto K. Clinical observation of blood loss reduced by tranexamic acid during and after cesarean section: a multi centre randomized trial. Eur J Obstet Gynaecol Reprod Biol. 2004;112(2):154-7.

4. As AK, Hagen P, Webb JB. Tranexamic acid in management of PPH. Br J Obstet Gynaecol. 1996;103(12):1250-1.

5. Yang H, Zheng S, Shi C. Clinical study on the efficacy of tranexamic acid in reducing postpartum blood lossa randomized multicentre trial. Zhonghua Fu Chan Zazhi. 2001;36(10):590-2.

6. Peitsidis P, Kadir RA. Tranexamic acid in pregnancy and postpartum. Expert Opin Pharmacother. 2011;12(4):503-16.
7. Leduc D, Senikas V. Active management of third stage of labour: prevention and treatment of PPH. J Obset Gynaecol Can. 2009;31(10):980-93.

8. Novikova N, Hofmeyr GJ. Tranexamic acid for preventing postpartum haemorrhage. Cochrane Database Syst Rev. 2010;(7):CD007872.

9. Soltani H, Hutchon DR. Timing of prophylactic uterotonics for third stage of labour after vaginal birth. Cochrane Database Syst Rev. 2010;4(8):CD006173.

10. Tesseir V, Pierre F. Risk of PPH during labour and clinical and pharmacological prevention. J Obset Gynaecol. 2004;33:4529-56.

11. Sekhavat L, Tabatabaai A. Efficacy of tranexamic acid in reducing blood loss after cesaerean section. $\mathrm{J}$ Matern Fetal Neonatal Med. 2009;22(1):72-5.

12. Litch JA. Program for appropriate technology and health. Seattle: AMTSL. 2004;132.

13. Gokhan. Routine practice of using tranexamic acid in AMTSL. NCT01338454, Bakirkoy; 2011.

14. La Londe A, Daviss BA. PPH today: ICM/FIGO initiative 2004 - 2006. Int J Obset Gynaecol. 2006;94:243-53.

Cite this article as: Nandhini CC, Shanmugapriya. The role of parenteral tranexamic acid in reducing blood loss in normal labour. Int $\mathrm{J}$ Reprod Contracept Obstet Gynecol 2020;9:4558-61. 